\title{
The Protective Role of $\beta$-Carotene and Hesperidin on Some Hematological and Myocardial Measurements against Imidacloprid Toxicity in Albino Rats
}

\author{
M. A. Bashandy ${ }^{1}$, E. I. El Zawahry ${ }^{1}$, S. A. Bashandy ${ }^{2}$ and M. F. Abdel Naby ${ }^{1}$ \\ 1. Zoology Department, Faculty of Science, Al-Azhar University, Cairo 11651, Egypt \\ 2. Department of Pharmacology, Medical Division, National Research Centre, 33 EL Bohouth St., Giza 12622, Egypt
}

\begin{abstract}
Neonicotinoids including IM (Imidacloprid) are widely used as plant systemic insecticides. Several studies have indicated that pesticide toxicity may be associated with the enhanced production of ROS (reactive oxygen species). Both $\beta$-carotene ( $\beta C$ ) and hesperidin $(\mathrm{H})$ have an antioxidant property and quench free radicals. This study aimed to clarify the protective role of $\beta$-carotene and hesperidin as natural antioxidants on IM induced toxicity in hematological parameters and markers of cardiac muscle activity in male albino rats. The treatment of rats with IM showed a significant decrease in hemoglobin (Hb \%), MCH (mean corpuscular hemoglobin), MCHC (mean corpuscular hemoglobin concentration), HCT (hematocrit) values and RBCs count comparing with control group. On the other hand, MCV (mean corpuscular volume), WBCs (white blood cells) and Plts (platelets) count pronounced a significant increase in IM group comparing to control. Also, $\alpha \mathrm{FP}$ (plasma alpha fetoprotein), CEA (carcinoembryonic antigen), CK (creatine kinase), CK-MB (creatine phosphokinase myocardial band) and LDH (lactate dehydrogenase) clarify a significant increase in IM group comparing to control. Both $\beta$-carotene and hesperidin mitigate the deleterious effects of IM on previous parameters. $\beta$-Carotene and hesperidin may protect hematopoietic system and heart muscle against toxicity of IM. These improvements of the results clarify the protective effect of the used antioxidants. Conclusion: $\beta$-carotene and hesperidin, natural antioxidants, have a protective effect against IM evoked hematological and biochemical changes.
\end{abstract}

Key words: $\beta$-carotene, hesperidin, IM, blood cells, cardiac enzymes, cancer markers.

\section{Introduction}

Pesticide toxicity may be associated with the enhanced production of ROS (reactive oxygen species), which could explain the multiple types of toxic responses observed. The production of ROS is caused by a mechanism in which xenobiotics, toxicants and pathological conditions may produce oxidative stress and induce damage to the liver, kidney and brain tissue [1]. Immediate human health hazards from pesticides include mild headaches, flu, skin rashes, blurred vision and other neurological disorders, and rarely, paralysis, blindness, and even death long run health impacts include cancer,

Corresponding author: Mohamed Fathy Abdel-Naby Ahmed, MSc of Science, research fields: zoology and pharmacology. infertility, miss-carriage, male sterility, birth defects, and effects on the nervous system [2]. Neonicotinoids are widely used in plant systemic insecticides developed in the last some decades, IM (Imidacloprid) was launched in 1991 for the first time by Bayer Crop-Science [3].

IM is an extensive pesticide used for crop protection worldwide from the last decade due to its low soil persistence and high insecticidal activity at very low application rate and binding affinity at the nAChR (nicotinic acetylcholine receptor) [4].

IM-treated rats showed a significant decrease in RBCs count, $\mathrm{Hb}$ content and MCHC (mean corpuscular hemoglobin concentration) values [5]. IM exhibited a significant increase in total leucocytes count [6]. Oral administration of IM to male albino rats led to a significant decrease in $\mathrm{Hb}, \mathrm{PCV}, \mathrm{MCV}$ 
(mean corpuscular volume), $\mathrm{MCH}$ (mean corpuscular hemoglobin) and MCHC (mean corpuscular hemoglobin concentration) [7].

Although oxidation reactions are crucial for life, they can also be damaging; hence, plants and animals maintain complex systems of multiple types of antioxidants, such as glutathione, vitamin $\mathrm{C}$ and vitamin $\mathrm{E}$ as well as enzymes such as catalase, superoxide dismutase and various peroxidases. Low levels of antioxidants or inhibition of the antioxidant enzymes, cause oxidative stress and may damage or kill cells, as oxidative stress might be an important part of many human diseases, in addition to these use of natural antioxidants in medicine. For many years chemists have shown that free radicals cause oxidation which can be controlled or prevented by a number of antioxidants substances [8].

Epidemiological studies have shown that populations that frequently consume vegetables containing vitamins $\mathrm{A}, \mathrm{C}$, and $\mathrm{E}$ and beta-carotene $(\beta C)$ have a lower incidence and risk of developing cancer and heart disease. Naturally occurring carotenoids and flavonoids possess free radical scavenging properties and offer cytoprotection from oxidative injury. Beta-carotene $(\beta C)$ and other carotenoids exert antioxidant functions such as the quenching of singlet oxygen and other electronically excited molecules that are produced by photoexcitation or chemiexcitation reactions. They further react with peroxyl or alkoxyl radicals [9].

Beta-carotene $(\beta C)$ is found in many foods that are orange in color, including sweet potatoes, carrots, cantaloupe, squash, apricots, pumpkin and mangoes. Some green, leafy vegetables, including collard greens, spinach and kale are also rich in beta-carotene, in another study, $\beta C$ was shown to decrease mitomycin $\mathrm{C}$-induced sister chromatic exchange frequencies in lymphocyte cultures obtained from Down's syndrome patients, furthermore, $\beta \mathrm{C}$ and folic acid revealed positive effects on mitomycin $\mathrm{C}$-induced DNA breaks and apoptosis of endometrial stromal cells, as determined by ultra-structural examinations; accordingly, $\beta \mathrm{C}$ reduced caspase- 3 activity [10]. The chemical abilities of $\beta C$ to quench singlet oxygen and to inhibit peroxyl free-radical reactions are well established, characteristics of $\beta C$ as an efficient antioxidant play an important role in decreasing the incidence of cancer [11] and cardiovascular diseases [12].

Flavonoids are an important group of polyphenolic compounds which play a protective role by inhibition of enzymes of oxygen-reduction pathways and sequestration of transient metal cautions and also quenching free radicals [13]. Hesperidin, a flavanone glycoside found abundantly in citrus fruits, possesses a wide range of pharmacological properties including potential anti-inflammatory and anticancer effects [14]. Hesperidin induces cell growth arrest apoptosis in a large variety of cells including colon and pancreatic cancer cells [15]. Hesperidin may be associated with potential benefits for the prevention of diseases, like decreased capillary permeability, inflammation, microbial infection and carcinogenic effects. A number of researchers have examined the antioxidant activity and radical scavenging properties of hesperidin using a variety of assay systems [16].

Hesperidin is a flavonoid found mainly in citrus fruits. Flavonoids are polyphenolic compounds, which directly quench free radicals and inhibit enzymes of oxygen-reduction pathways, hesperidin was also shown to have a wide spectrum of pharmacological effects including anti-inflammatory, anti-carcinogenic, antihypertensive and anti-atherogenic effects [17]. Hesperidin improves the vascular integrity, decreases capillary permeability and is given as a supplement to patients with blood vessel fragility, also shows anti-inflammatory and immunomodulatory effects [18].

Hesperidin has non-toxic activity in normal cells, while it is suppresses cell proliferation in several cancer types. Hesperidin is known to have 
anti-inflammatory, anti-viral, UV protecting, antioxidant, pro-apoptotic, anti-proliferative, anti-tumor properties, and protective effects against cerebrovascular disease and diabetes mellitus [19]. In addition, hesperidin as a radio-protective and chemo-protective therapeutic agent is expected to prevent invasion or metastasis of human cancers [20]. Anti-cancer effect of hesperidin was studied in tumor implanted animal models or culture cell lines of several cancer types, including colon cancer, bladder cancer, hepatocarcinoma cancer and breast cancer, but the mechanism of this compound was not understood [21].

\section{Material and Methods}

\subsection{Material}

\subsubsection{Chemicals}

(1). IM: was obtained from the Agricultural Research Center, Cairo, Egypt. It was dissolved in dist. water and administrated daily by oral at two different doses, high dose $1 / 5 \mathrm{LD}_{50}(90 \mathrm{mg} / \mathrm{kg}$ b.wt.) and low dose $1 / 10 \mathrm{LD}_{50}$ (45 mg/kg b.wt.) for 30 days.

(2). Beta-carotene $(\beta C)$ : was obtained from El-Goumhouria Co. for Trading Medicine, Cairo, Egypt. It was dissolved in corn oil and given daily orally in a dose of $20 \mathrm{mg} / \mathrm{kg}$ b.wt. before administration of IM for 30 days.

(3). Hesperidin $(\mathrm{H})$ : was obtained from Sigma Co. for Trading Medicine, Cairo, Egypt. It was dissolved in dist. water and given daily orally in a dose of 100 $\mathrm{mg} / \mathrm{kg}$ b.wt. before administration of IM for 30 days.

\subsubsection{Animals and Experimental Design}

Fifty four adult male albino rats (Rattus norvegicus), weighting 140-160 g were used, housed in separated galvanized iron cages in a thermostatically controlled room under $12 \mathrm{~h}$ light/dark cycle. They were maintained on standard laboratory diet with free access to water.

Rats were randomly divided into the following groups:

Group I received the vehicle and was considered as normal control $(\mathrm{n}=6$ rats $)$.

Group II

A. Animal received a daily low dose of imidacloprid (45 mg/kg, 1/10 $\mathrm{LD}_{50}$ ) orally for 30 days $(\mathrm{n}=6$ rats $)$.

B. Animal received a daily high dose of imidacloprid (90 mg/kg, 1/5 $\mathrm{LD}_{50}$ ) orally for 30 days $(\mathrm{n}=6$ rats $)$.

Group III

A. The rats were treated daily with low dose of imidacloprid $(45 \mathrm{mg} / \mathrm{kg}$ ) and beta-carotene at dose level of $20 \mathrm{mg} / \mathrm{kg}$ [22] orally or 30 days ( $\mathrm{n}=6$ rats).

B. The animals received a daily high dose of imidacloprid $(90 \mathrm{mg} / \mathrm{kg})$ and beta carotene $(20 \mathrm{mg} / \mathrm{kg})$ orally for 30 days $(\mathrm{n}=6$ rats).

Group IV

A. The rats received a daily low dose of imidacloprid $(45 \mathrm{mg} / \mathrm{kg})$ and hesperidin at dose of 100 $\mathrm{mg} / \mathrm{kg}$ [23] orally for 30 days ( $\mathrm{n}=6$ rats).

B. The animals received a single daily high dose of imidacloprid and hesperidin $(100 \mathrm{mg} / \mathrm{kg})$ orally for 30 days $(\mathrm{n}=6$ rats $)$.

Group V

A. The rats received a low dose of imidacloprid orally after administration of beta-carotene and hesperidin in combination for 30 days ( $\mathrm{n}=6$ rats).

B. Each animal received a daily high dose of imidacloprid orally after administration of beta-carotene and hesperidin in combination for 30 days ( $\mathrm{n}=6$ rats).

Both beta-carotene and hesperidin were pretreated orally daily for 2 weeks before imidacloprid treatment.

\subsubsection{Samples Collection}

At the end of the experiment, blood was withdrawn from retro-orbital plexus of eyes. Blood portion collected upon anticoagulant (EDTA) for the hematological measurements, and other portion was collected in other centrifuge tube for serum parameters, where blood sample was centrifuged at $4,000 \mathrm{rpm}$ for $10 \mathrm{~min}$ by using centrifuge. Non-hemolized serum stored at $-20{ }^{\circ} \mathrm{C}$ till for 
biochemical analysis.

\subsection{Methods}

\subsubsection{Determination of Complete Blood Count}

Complete blood counts [hemoglobin ( $\mathrm{Hb} \%)$, HCT (hematocrit), RBCs count, MCV, MCH (mean corpuscular hemoglobin), MCHC (mean corpuscular hemoglobin concentration), Plt (platelets) count and total WBCs (white blood cells) count were evaluated [24] using SYSMEX reagents and Cell blood counter (SYSMEX)—Model XT 2000 I, A double capillary, full automatic, Japan.

\subsubsection{Determination of Cardiac Enzymes}

Serum CK (creatine kinase), CK-MB (serum creatine phosphokinase myocardial band) and serum LDH (lactate dehydrogenase) were done [25] using BECKMAN COULTER reagents and BECKMAN COULTER analyzer-Model AU 480, Full automatic, Japan.

\subsubsection{Determination of Tumor Markers}

$\alpha$ FP (Alpha fetoprotein) and CEA (carcinoembryonic antigen) in serum were done [26] using Elecsys reagents and COBAS analyzer-Model E 411, Full automatic, Japan

\subsubsection{Statistical Analysis}

The data were presented as mean value $\pm \mathrm{SE}$ (standard error). The significance of difference between the mean values was evaluated using Student's t-test [27].

\section{Results}

\subsection{Hematological Results}

As shown in Table 1 or Fig. 1, the results indicated a significant decrease $(p \leq 0.05)$ in $\mathrm{Hb} \%$ and Hct of rats treated with IM comparing with control group, while both $\beta$-carotene or/and hesperidin groups showed significant increases comparing with IM group. On the other hand, WBCs and Plt count of rats treated with IM were significantly elevated comparing with control group, while both $\beta$-carotene or/and hesperidin groups showed significant decreases comparing with IM group.

The results presented in Table 2 and Fig. 2, pronounced a significant decrease $(p \leq 0.05)$ in $\mathrm{MCH}$, $\mathrm{MCHC}$ and RBCs count of rats treated with IM groups at the low and high doses, while MCV of rats treated with IM elevated significantly comparing with untreated group. Both beta-carotene or/and hesperidin reduced the deleterious effects of IM on blood measurements comparing with control group. On the other hand, $\mathrm{MCH}, \mathrm{MCHC}$ and $\mathrm{RBCs}$ count of $\beta \mathrm{C}+\mathrm{H}+\mathrm{IM}$ group did not change significantly compared with control group.

Table 1 Protective effect of $\beta$-carotene and hesperidin against Imidacloprid toxicity on $\mathrm{Hb} \%$, Hct, WBCs and PIt in albino rats.

\begin{tabular}{|c|c|c|c|c|c|c|c|c|c|}
\hline \multirow{3}{*}{ Group } & \multirow{3}{*}{ C } & \multirow{2}{*}{\multicolumn{2}{|c|}{ IM }} & \multicolumn{6}{|c|}{ Antioxidants and insecticide } \\
\hline & & & & \multicolumn{2}{|c|}{$\mathrm{BC}+\mathrm{IM}$} & \multicolumn{2}{|c|}{$\mathrm{H}+\mathrm{IM}$} & \multicolumn{2}{|c|}{$\mathrm{BC}+\mathrm{H}+\mathrm{IM}$} \\
\hline & & $\begin{array}{l}1 / 5 \\
\mathrm{LD}_{50}\end{array}$ & $1 / 10 \mathrm{LD}_{50}$ & $\begin{array}{l}1 / 5 \\
\mathrm{LD}_{50}\end{array}$ & $1 / 10 \mathrm{LD}_{50}$ & $1 / 5 \mathrm{LD}_{50}$ & $1 / 10 \mathrm{LD}_{50}$ & $1 / 5 \mathrm{LD}_{50}$ & $1 / 10 \mathrm{LD}_{50}$ \\
\hline & & $*$ & $*$ & $* \mathrm{a}$ & $* \mathrm{a}$ & $* \mathrm{a}$ & $*$ & $* \mathrm{a}$ & $* \mathrm{ac}$ \\
\hline $\begin{array}{l}\mathrm{Hb} \% \\
(\mathrm{gm} / \mathrm{dl})\end{array}$ & $\begin{array}{l}16.90 \\
\pm 0.20\end{array}$ & $\begin{array}{l}12.40 \\
\pm 0.46\end{array}$ & $\begin{array}{l}13.63 \\
\pm 0.35\end{array}$ & $\begin{array}{l}14.00 \\
\pm 0.35\end{array}$ & $\begin{array}{l}14.70 \\
\pm 0.38\end{array}$ & $\begin{array}{l}13.80 \\
\pm 0.38\end{array}$ & $\begin{array}{l}14.27 \\
\pm 0.28\end{array}$ & $\begin{array}{l}14.50 \\
\pm 0.36\end{array}$ & $\begin{array}{l}15.47 \\
\pm 0.27\end{array}$ \\
\hline $\begin{array}{l}\text { Hct } \\
(\%)\end{array}$ & $\begin{array}{l}51.67 \\
\pm 2.32\end{array}$ & $\begin{array}{l}* \\
35.60 \\
\pm 1.08\end{array}$ & $\begin{array}{l}* \\
38.72 \\
\pm 0.89\end{array}$ & $\begin{array}{l}* \mathrm{a} \\
39.47 \\
\pm 0.62\end{array}$ & $\begin{array}{l}* \\
40.27 \\
\pm 1.27\end{array}$ & $\begin{array}{l}* \mathrm{a} \\
38.93 \\
\pm 1.03\end{array}$ & $\begin{array}{l}* \\
40.03 \\
\pm 0.51\end{array}$ & $\begin{array}{l}* \mathrm{a} \\
41.70 \\
\pm 0.96\end{array}$ & $\begin{array}{l}* \mathrm{a} \\
42.02 \\
\pm 0.93\end{array}$ \\
\hline $\begin{array}{l}\text { WBCs } \\
\times 10^{3} / \mathrm{mm}^{3}\end{array}$ & $\begin{array}{l}9.40 \\
\pm 0.56\end{array}$ & $\begin{array}{l}* \\
18.70 \\
\pm 0.91\end{array}$ & $\begin{array}{l}* \\
16.80 \\
\pm 0.69\end{array}$ & $\begin{array}{l}* \mathrm{a} \\
14.60 \\
\pm 0.49\end{array}$ & $\begin{array}{l}* \mathrm{a} \\
13.50 \\
\pm 0.66\end{array}$ & $\begin{array}{l}* \mathrm{a} \\
15.63 \\
\pm 0.52\end{array}$ & $\begin{array}{l}* a \\
14.60 \\
\pm 0.44\end{array}$ & $\begin{array}{l}* \mathrm{ac} \\
13.97 \\
\pm 0.42\end{array}$ & $\begin{array}{l}* \mathrm{ac} \\
12.40 \\
\pm 0.59\end{array}$ \\
\hline $\begin{array}{l}\text { Plt } \\
\times 10^{3} / \mathrm{uL}\end{array}$ & $\begin{array}{l}468.00 \\
\pm 41.80\end{array}$ & $\begin{array}{l}* \\
1149.00 \\
\pm 102.15\end{array}$ & $\begin{array}{l}* \\
991.00 \\
\pm 94.11\end{array}$ & $\begin{array}{l}* \mathrm{a} \\
715.00 \\
\pm 44.51\end{array}$ & $\begin{array}{l}* \mathrm{a} \\
684.00 \\
\pm 60.52\end{array}$ & $\begin{array}{l}* \mathrm{a} \\
761.67 \\
\pm 74.00\end{array}$ & $\begin{array}{l}* \mathrm{a} \\
742.00 \\
\pm 51.85\end{array}$ & $\begin{array}{l}* \mathrm{*} \\
701.00 \\
\pm 76.25\end{array}$ & $\begin{array}{l}* a \\
693.00 \\
\pm 75.15\end{array}$ \\
\hline
\end{tabular}



Myocardial Measurements against Imidacloprid Toxicity in Albino Rats
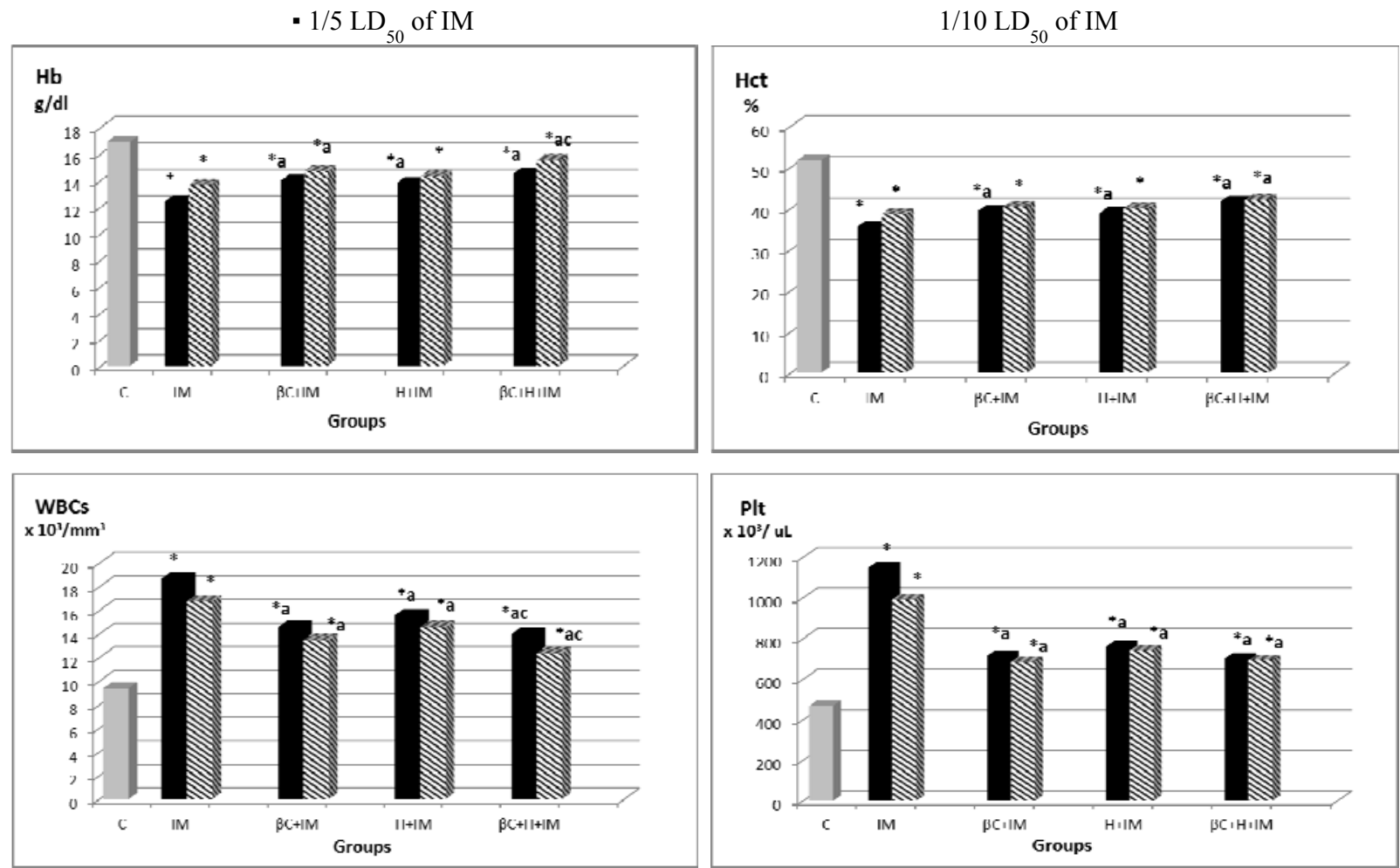

Fig. 1 Protective effect of $\beta$-carotene and hesperidin against Imidacloprid toxicity on $\mathrm{Hb} \%$, Het, WBCs and PIt in albino rats.

where:

C: Control, IM: Imidacloprid, BC: Beta-Carotene, H: Hesperidin.

Each value is the mean $\pm S E, n=6$.

*: Significant difference from Control group, $p^{*} \leq 0.05$.

a: Significant difference from IM group, $p^{\text {a }} \leq 0.05$.

b: Significant difference from BC+IM group, $p^{b} \leq 0.05$.

c: Significant difference from $\mathrm{H}+\mathrm{IM}, p^{\mathrm{c}} \leq 0.05$.

Table 2 Protective effect of $\beta$-carotene and hesperidin against Imidacloprid toxicity on RBCs, MCV, MCH and MCHC in albino rats.

\begin{tabular}{|c|c|c|c|c|c|c|c|c|c|}
\hline \multirow{3}{*}{ Group } & \multirow{3}{*}{$\mathrm{C}$} & \multirow{2}{*}{\multicolumn{2}{|c|}{ IM }} & \multicolumn{6}{|c|}{ Antioxidants and insecticide } \\
\hline & & & & \multicolumn{2}{|c|}{$\mathrm{BC}+\mathrm{IM}$} & \multicolumn{2}{|c|}{$\mathrm{H}+\mathrm{IM}$} & \multicolumn{2}{|c|}{$\mathrm{BC}+\mathrm{H}+\mathrm{IM}$} \\
\hline & & $\begin{array}{l}1 / 5 \\
\mathrm{LD}_{50} \\
\end{array}$ & $1 / 10 \mathrm{LD}_{50}$ & $\begin{array}{l}1 / 5 \\
\mathrm{LD}_{50} \\
\end{array}$ & $1 / 10 \mathrm{LD}_{50}$ & $1 / 5 \mathrm{LD}_{50}$ & $1 / 10 \mathrm{LD}_{50}$ & $1 / 5 \mathrm{LD}_{50}$ & $1 / 10 \mathrm{LD}_{50}$ \\
\hline & & $*$ & $*$ & $*$ & $*$ & $*$ & $*$ & $\mathrm{ac}$ & $\mathrm{ac}$ \\
\hline$\times 10^{6} / \mathrm{mm}^{3}$ & $\begin{array}{l}8.35 \\
\pm 0.17\end{array}$ & $\begin{array}{l}5.40 \\
\pm 0.54\end{array}$ & $\begin{array}{l}5.73 \\
\pm 0.73\end{array}$ & $\begin{array}{l}6.23 \\
\pm 0.63\end{array}$ & $\begin{array}{l}6.43 \\
\pm 0.84\end{array}$ & $\begin{array}{l}5.95 \\
\pm 0.50\end{array}$ & $\begin{array}{l}6.42 \\
\pm 0.37\end{array}$ & $\begin{array}{l}7.43 \\
\pm 0.52\end{array}$ & $\begin{array}{l}7.87 \\
\pm 0.32\end{array}$ \\
\hline $\begin{array}{l}\text { MCV } \\
\text { (fl) }\end{array}$ & $\begin{array}{l}57.85 \\
\pm 3.57\end{array}$ & $\begin{array}{l}* \\
93.00 \\
\pm 8.49\end{array}$ & $\begin{array}{l}* \\
92.35 \\
\pm 7.25\end{array}$ & $\begin{array}{l}* \\
75.20 \\
\pm 7.48\end{array}$ & $\begin{array}{l}75.03 \\
\pm 9.75\end{array}$ & $\begin{array}{l}* \\
77.38 \\
\pm 6.14\end{array}$ & $\begin{array}{l}* \mathrm{a} \\
71.12 \\
\pm 4.16\end{array}$ & $\begin{array}{l}a \\
68.97 \\
\pm 5.72\end{array}$ & $\begin{array}{l}\mathrm{a} \\
61.82 \\
\pm 4.83\end{array}$ \\
\hline $\begin{array}{l}\mathrm{MCH} \\
\text { (pg) }\end{array}$ & $\begin{array}{l}27.10 \\
\pm 2.10\end{array}$ & $\begin{array}{l}23.88 \\
\pm 2.27\end{array}$ & $\begin{array}{l}24.80 \\
\pm 1.96\end{array}$ & $\begin{array}{l}23.45 \\
\pm 2.52\end{array}$ & $\begin{array}{l}24.33 \\
\pm 2.90\end{array}$ & $\begin{array}{l}23.83 \\
\pm 2.16\end{array}$ & $\begin{array}{l}24.13 \\
\pm 1.08\end{array}$ & $\begin{array}{l}* \\
19.86 \\
\pm 1.43\end{array}$ & $\begin{array}{l}25.13 \\
\pm 1.35\end{array}$ \\
\hline $\begin{array}{l}\text { MCHC } \\
(\mathrm{g} / \mathrm{dL})\end{array}$ & $\begin{array}{l}37.55 \\
\pm 0.45\end{array}$ & $\begin{array}{l}* \\
27.55 \\
\pm 1.02\end{array}$ & $\begin{array}{l}* \\
30.30 \\
\pm 0.77\end{array}$ & $\begin{array}{l}* \mathrm{a} \\
31.12 \\
\pm 0.76\end{array}$ & $\begin{array}{l}* \mathrm{a} \\
32.67 \\
\pm 0.86\end{array}$ & $\begin{array}{l}* a \\
30.68 \\
\pm 0.84\end{array}$ & $\begin{array}{l}* \\
31.72 \\
\pm 0.63\end{array}$ & $\begin{array}{l}* \mathrm{a} \\
32.23 \\
\pm 0.81\end{array}$ & $\begin{array}{l}* \mathrm{ac} \\
34.38 \\
\pm 0.60\end{array}$ \\
\hline
\end{tabular}



Myocardial Measurements against Imidacloprid Toxicity in Albino Rats
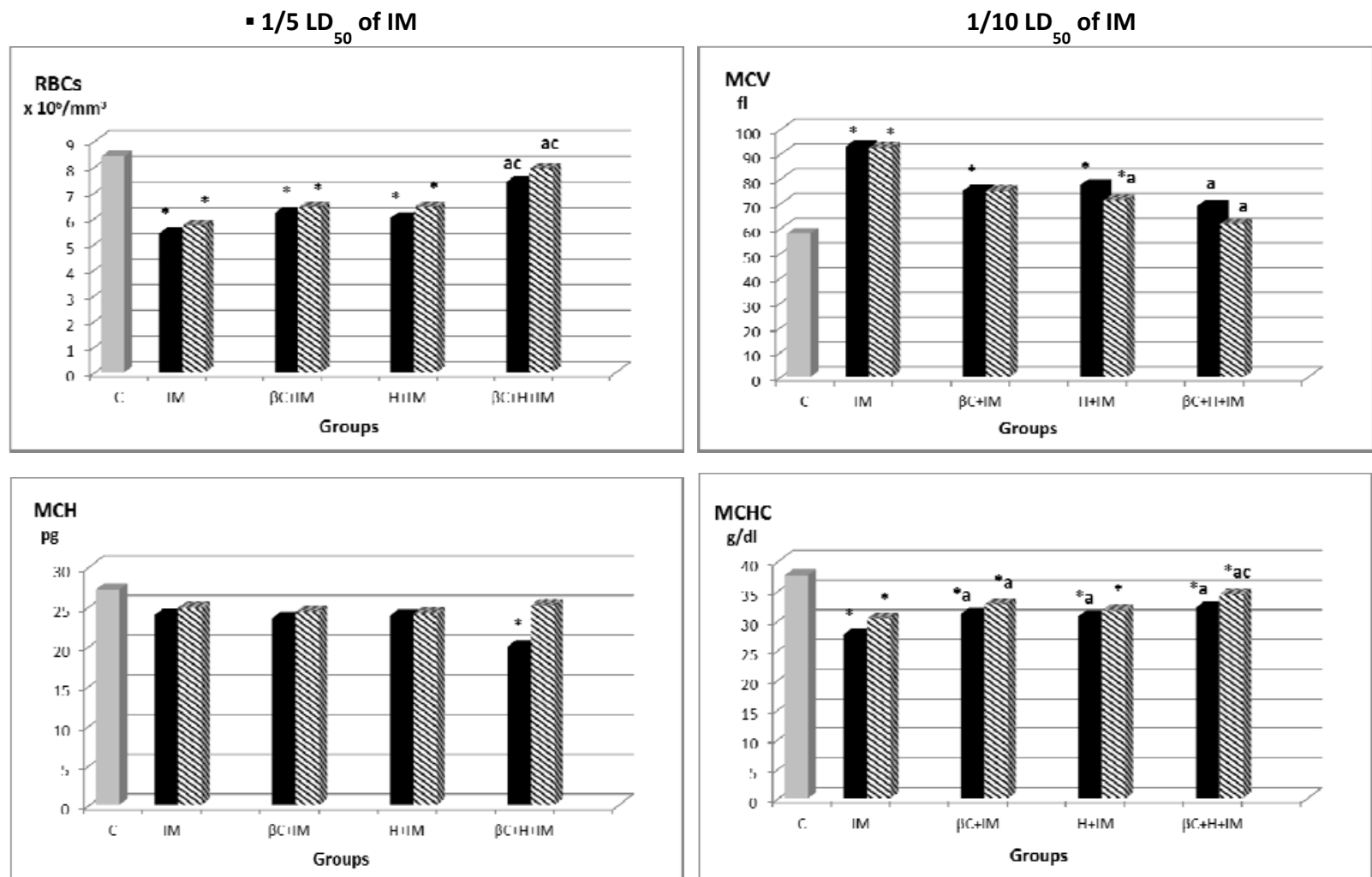

Fig. 2 Protective effect of $\beta$-carotene and hesperidin against Imidacloprid toxicity on RBCs, MCV, MCH and MCHC in albino rats.

where:

C: Control, IM: Imidacloprid, BC: Beta Carotene, H: Hesperidin.

Each value is the mean \pm SE, $n=6$.

*: Significant difference from Control group, $p^{*} \leq 0.05$.

a: Significant difference from IM group, $p^{\mathrm{a}} \leq 0.05$.

b: Significant difference from BC+IM group, $p^{b} \leq 0.05$.

c: Significant difference from $\mathrm{H}+\mathrm{IM}, p^{\mathrm{c}} \leq 0.05$.

Table 3 Protective effect of $\beta$-arotene and hesperidin against Imidacloprid induced changes on cardiac muscle enzymes and cancer markers.

\begin{tabular}{|c|c|c|c|c|c|c|c|c|c|}
\hline \multirow{3}{*}{ Group } & \multirow{3}{*}{$\mathrm{C}$} & \multirow{2}{*}{\multicolumn{2}{|c|}{ IM }} & \multicolumn{6}{|c|}{ Antioxidants and insecticide } \\
\hline & & & & \multicolumn{2}{|c|}{$\mathrm{BC}+\mathrm{IM}$} & \multicolumn{2}{|c|}{$\mathrm{H}+\mathrm{IM}$} & \multicolumn{2}{|c|}{$\mathrm{BC}+\mathrm{H}+\mathrm{IM}$} \\
\hline & & $\begin{array}{l}1 / 5 \\
\mathrm{LD}_{50} \\
\end{array}$ & $1 / 10 \mathrm{LD}_{50}$ & $1 / 5 \mathrm{LD}_{50}$ & $1 / 10 \mathrm{LD}_{50}$ & $1 / 5 \mathrm{LD}_{50}$ & $1 / 10 \mathrm{LD}_{50}$ & $1 / 5 \mathrm{LD}_{50}$ & $1 / 10 \mathrm{LD}_{50}$ \\
\hline & & $*$ & $*$ & $* \mathrm{a}$ & $* \mathrm{a}$ & $* \mathrm{a}$ & * & *abc & $* \mathrm{ac}$ \\
\hline $\begin{array}{l}\text { CK } \\
(\mathrm{U} / \mathrm{L})\end{array}$ & $\begin{array}{l}117.00 \\
\pm 9.83\end{array}$ & $\begin{array}{l}286.00 \\
\pm 9.06\end{array}$ & $\begin{array}{l}239.00 \\
\pm 22.33\end{array}$ & $\begin{array}{l}210.00 \\
\pm 10.17\end{array}$ & $\begin{array}{l}181.00 \\
\pm 17.39\end{array}$ & $\begin{array}{l}251.00 \\
\pm 13.33\end{array}$ & $\begin{array}{l}213.83 \\
\pm 7.45\end{array}$ & $\begin{array}{l}184.00 \\
\pm 7.77\end{array}$ & $\begin{array}{l}175.17 \\
\pm 8.74\end{array}$ \\
\hline & & $*$ & $*$ & $*$ & $*_{\mathrm{a}}$ & $*_{\mathrm{a}}$ & $* \mathrm{a}$ & $* a c$ & $* \mathrm{ac}$ \\
\hline (U/L) & $\begin{array}{l}22.00 \\
\pm 1.06\end{array}$ & $\begin{array}{l}53.00 \\
\pm 4.94\end{array}$ & $\begin{array}{l}48.00 \\
\pm 3.35\end{array}$ & $\begin{array}{l}43.00 \\
\pm 3.69\end{array}$ & $\begin{array}{l}35.00 \\
\pm 2.83\end{array}$ & $\begin{array}{l}49.00 \\
\pm 2.61\end{array}$ & $\begin{array}{l}39.17 \\
\pm 2.11\end{array}$ & $\begin{array}{l}36.33 \\
\pm 2.96\end{array}$ & $\begin{array}{l}30.00 \\
\pm 2.25\end{array}$ \\
\hline LDH & & * & * 88783 & $* a$ & $* a$ & & $* a$ & *ac & $* \mathrm{ac}$ \\
\hline$(\mathrm{U} / \mathrm{L})$ & $\begin{array}{l}350.17 \\
\pm 27.63\end{array}$ & $\begin{array}{l}1001.17 \\
\pm 70.25 \\
*\end{array}$ & $\begin{array}{l}887.83 \\
\pm 63.71 \\
*\end{array}$ & $\begin{array}{l}707.33 \\
\pm 85.84 \\
*_{a}\end{array}$ & $\begin{array}{l}622.67 \\
\pm 54.54 \\
*\end{array}$ & $\begin{array}{l}921.67 \\
\pm 96.43 \\
* a\end{array}$ & $\begin{array}{l}715.33 \\
\pm 48.61 \\
\end{array}$ & $\begin{array}{l}630.83 \\
\pm 92.52 \\
*\end{array}$ & $\begin{array}{l}504.83 \\
\pm 43.40 \\
*\end{array}$ \\
\hline $\begin{array}{l}\alpha-\mathrm{FP} \\
(\mathrm{IU} / \mathrm{mL})\end{array}$ & $\begin{array}{l}3.60 \\
\pm 0.12\end{array}$ & $\begin{array}{l}8.10 \\
\pm 0.60\end{array}$ & $\begin{array}{l}7.70 \\
\pm 0.25\end{array}$ & $\begin{array}{l}6.20 \\
\pm 0.51\end{array}$ & $\begin{array}{l}5.40 \\
\pm 0.38\end{array}$ & $\begin{array}{l}6.60 \\
\pm 0.27\end{array}$ & $\begin{array}{l}\mathrm{a} \\
6.08 \\
\pm 0.39\end{array}$ & $\begin{array}{l}5.70 \\
\pm 0.35\end{array}$ & $\begin{array}{l}4.98 \\
\pm 0.44\end{array}$ \\
\hline $\begin{array}{l}\text { CEA } \\
(\mathrm{ng} / \mathrm{mL})\end{array}$ & $\begin{array}{l}2.80 \\
\pm 0.23\end{array}$ & $\begin{array}{l}* \\
9.60 \\
\pm 0.56\end{array}$ & $\begin{array}{l}* \\
7.12 \\
\pm 0.39\end{array}$ & $\begin{array}{l}* \mathrm{a} \\
5.00 \\
\pm 0.73\end{array}$ & $\begin{array}{l}* \mathrm{a} \\
4.20 \\
\pm 0.35\end{array}$ & $\begin{array}{l}* \mathrm{a} \\
5.73 \\
\pm 0.30\end{array}$ & $\begin{array}{l}* \mathrm{a} \\
4.80 \\
\pm 0.33\end{array}$ & $\begin{array}{l}* \mathrm{ac} \\
4.60 \\
\pm 0.34\end{array}$ & $\begin{array}{l}* a c \\
3.70 \\
\pm 0.30\end{array}$ \\
\hline
\end{tabular}




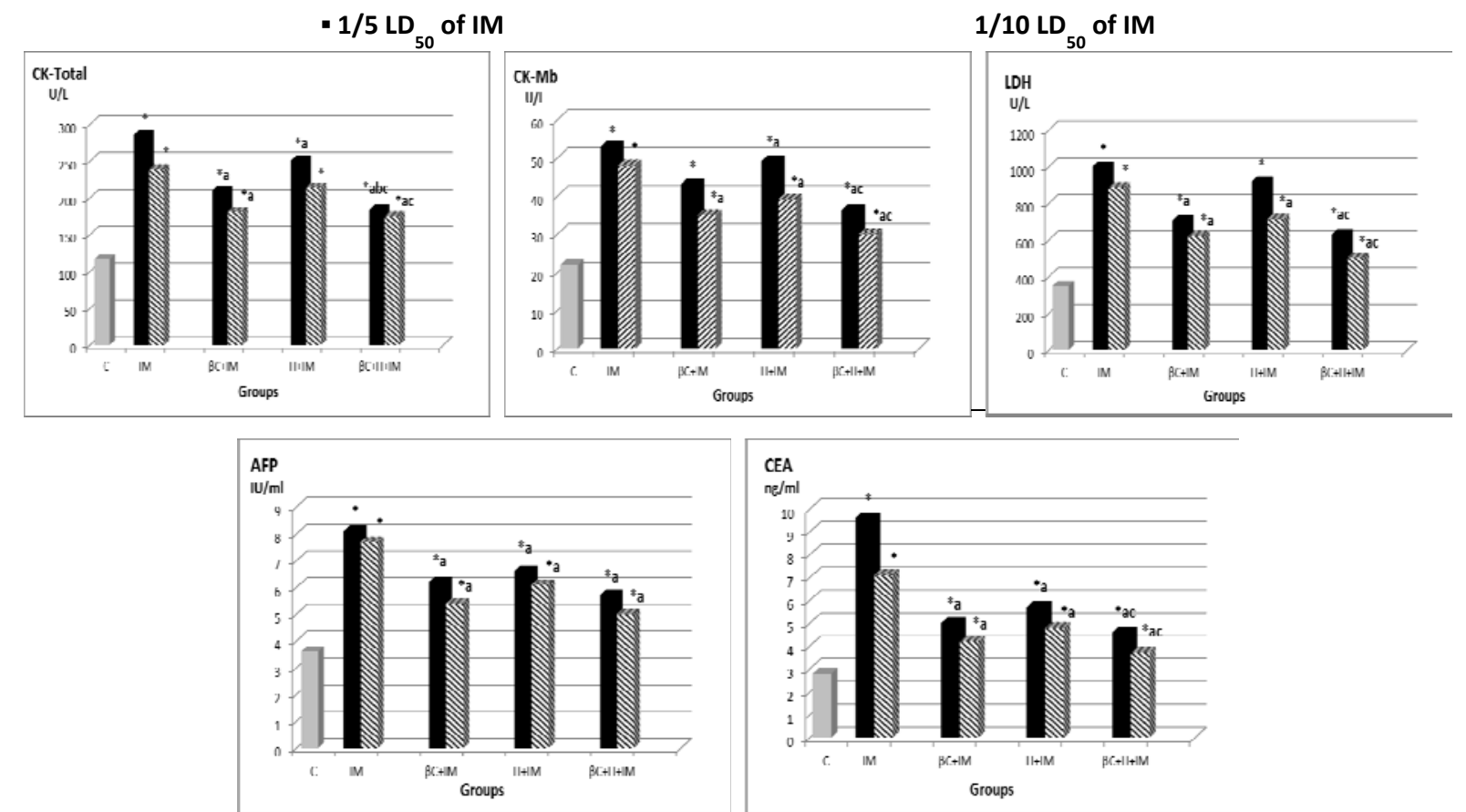

Fig. 3 Protective effect of $\beta$-carotene and hesperidin against Imidacloprid toxicity on CK-Total, CK-MB, LDH, $\alpha$-FP and CEA in albino rats.

where:

C: Control, IM: Imidacloprid, BC: Beta Carotene, H: Hesperidin.

Each value is the mean $\pm \mathrm{SE}, \mathrm{n}=6$.

$*$ : Significant difference from Control group, $p^{*} \leq 0.05$.

a: Significant difference from IM group, $p^{\mathrm{a}} \leq 0.05$.

b: Significant difference from $\mathrm{BC}+\mathrm{IM}$ group, $p^{\mathrm{b}} \leq 0.05$.

c: Significant difference from $\mathrm{H}+\mathrm{IM}, p^{\mathrm{c}} \leq 0.05$.

\subsection{Biochemical Results}

From Table 3 or Fig. 3 , the results showed a significant increase $(p \leq 0.05)$ in $\mathrm{CK}, \mathrm{CK}-\mathrm{Mb}, \mathrm{LDH}$, $\alpha \mathrm{FP}$ and CEA concentrations of rats treated with IM at the two used doses comparing with control. Both beta-carotene or/and hesperidin reduced the deleterious effects of IM on the cardiac enzymes and tumor markers.

\section{Discussion}

The obtained results showed a significant decrease in $\mathrm{Hb}, \mathrm{Hct}, \mathrm{RBCs}, \mathrm{MCH}$ and $\mathrm{MCHC}$ and significant increase in MCV, WBCs and Plt of rats treated with IM comparing with control that reflects the deleterious and toxic effects of the IM upon these hematological data which may be due to marked increase of the ROS

that causes stress effects upon its production and haemopoiesis from the bone marrow or its toxic effects on the liver, bone marrow and other vital organs, this is in agreement with the finding of Refs. [5] and [6] who recorded that IM-treated rats showed a significant decrease in $\mathrm{RBCs}$ count, $\mathrm{Hb}$ content and MCHC values and significant increase in total leucocytes count, also this is in agreement with the finding of Ref. [7] who concluded that oral administration of IM to male albino rats induced a significant decrease in $\mathrm{Hb}, \mathrm{PCV}, \mathrm{MCH}$ and $\mathrm{MCHC}$. On the other hand when $\beta$-carotene and hesperidin (separately or in combination) supplemented to rats given IM improved, the previous parameters and in addition to beside WBCs, Plt and MCV. The free radicals cause oxidation which can be controlled or prevented by both of $\beta C$ ( $\beta$-carotene) and hesperidin 
(H) which improves the vascular integrity, decreases capillary permeability and cell death by several mechanisms, such as scavenging oxygen radicals $[8,28,29]$. Oral supplementation with antioxidants appears to be effective for radioprotection of hematopoietic cells and improvement of animal survival, and modulation of apoptosis [30]. The decrease of oxidative stress in blood by hesperidin was associated with amelioration of the hematology profile [31].

The present investigation showed that there is significant increase in both of CK-Total, CK-Mb, LDH, AFP and CEA comparing with control that reflects the deleterious and toxic effects of the IM upon these biochemical results which may be due to marked increase of the ROS or decrease of the natural humeral antioxidants that cause toxic stress effects on the heart and other vital organs $[2,9,32]$.

On the other hand when $\beta$-carotene and hesperidin supplemented in separated or in combination reduced the changes in CK-Total, CK-Mb, LDH, AFP and CEA levels due to IM treatment that may reflect limiting of the toxicity of IM by the two antioxidants of the study. This is supported by the finding of Refs. [11] and [12] who found that $\beta C$ (beta-carotene) has a lower incidence and risk of developing cancer and heart disease mediated by free radicals, via quenching singlet oxygen and to inhibit peroxyl free-radical reactions. Our results are in agreement with the finding of Ref. [16]; Refs. [14] and [15] concluded that hesperidin possesses a wide range of pharmacological properties including potential anti-inflammatory and anticancer effects, hesperidin induces cell growth arrest apoptosis in a large variety of cells including colon and pancreatic cancer cells.

\section{Conclusions}

According to the results obtained in the present study, it is concluded that beta-carotene and hesperidin could be useful to attenuate biochemical and hematological changes induced by IM. Both beta-carotene and hesperidin may protect the hematopoietic system and heart from toxic effects of IM via their antioxidant effects. Moreover, IM appears carcinogenic and the two natural antioxidants exhibited anticarcenogenic property. Beta-carotene and hesperidin may protect from environmental pollutants and insecticides effects.

\section{References}

[1] El-Gendy, K. S., Aly, N. M., Mahmoud, F. H., Kenawy, A., and El-Sebae, A. K. 2010. "The Role of Vitamin C as Antioxidant in Protection of Oxidative Stress Induced by Imidacloprid." Food Chem. Toxicol. 48: 215-21.

[2] Wilson, J. S., and Otsuki, T. 2004. "To Spray or Not to Spray: Pesticides, Bananaexports and Food Safety." Food Policy 29: 131-46.

[3] Elbert, A., Haas, M., Thielert, W., and Nauen, R. 2007. “Applied Aspects of Neonicotinoid Uses." In Proc. XVI Internat Plant Prot. Cong, Glasgow, UK, 3, 620-1.

[4] Wang, R., Wang, Z., Yang, H., Wang, Y., and Deng, A. 2012. "Highly Sensitive and Specific Detection of Neonicotinoid Insecticide Imidacloprid in Environmental and Food Samples by a Polyclonal Antibody-Based Enzyme-Linked Immunosorbent Assay." Journal of the Science of Food and Agriculture 92 (6): 1253-60.

[5] El-Kashory, A. A., and El-Said, M. M. 2001. "Study of Aldosterone Level, Electrolytic Balance and Haematological Changes Following Exposure to Low Doses of Profenofos, Carbosulfan and Imidaclopride in Male Albino Rats." J. Egypt. Vet. Med. Assoc. pp. 61, 64.

[6] Mohany, M., Badr, G., Refaat, I., Garraud, O., and EI-Feki, M. 2012. "Thymoquinone Ameliorates Immunological and Histological Changes Induced by Exposure to Imidacloprid Insecticide." Toxicology Science 37 (1): 1-11.

[7] Soujanya, S., Lakshman, M., Anand-Kumar, A., and Gopala-Reddy, A. 2012. "Histopathological and Ultrastructural Changes Induced by Imidacloprid in Brain and Protective Role of Vitamin C in Rats." Journal of Chemical and Pharmaceutical Research 4 (9): 4307-18.

[8] Bjelakovic, G., Nikolova, D., Gluud, L. L., Simonetti, R. G., and Gluud, C. 2007. "Mortality in Randomized Trials of Antioxidant Supplements for Primary and Secondary Prevention: Systematic Review and Meta-Analysis." JAMA 297 (8): 842-57.

[9] Uenojo, M., Marostica-Junior, M. R., and Pastore, G. M. 2007. "Carotenoides: Propriedades, aplicacoes e biotransformacao para formacao de compostos de aroma." Quím. Nova 30: 616-22.

[10] Yilmaz, Z., Karabay, G., and Oktem, M. 2006. "The 
Apoptotic Effects of Mitomycin $\mathrm{C}$ on Human Endometrial Cell Cultures and Reversal of Its Effects by Beta-Carotene and Folic Acid." Acta. Physiol. Hung. 93: 41-51.

[11] Riboli, E., and Norat, T. 2003. "Epidemiologic Evidence of the Protective Effect of Fruit and Vegetables on Cancer Risk.” Am. J. Clin. Nutr. 78: 559S-69S.

[12] Oliveira, G. S., Figueiredo, A. S. P., Santos, R. S., and Vianna, L. M. 2007. "Effect of $\beta$-Carotene Supplementation on the Blood Pressure of Rats. [Efeito da suplementação de beta-caroteno na pressão arterial de ratos]. Rev. Nutr. 20: 39-45.

[13] Naik, S. R. 2003. "Antioxidants and Their Role in Biological Functions: An Overview.” Indian. Drugs 40: 501-16.

[14] Benavente-Garcia, O., and Castillo, J. 2008. "Update on Uses and Properties of Citrus Flavonoids: New Findings in Anticancer, Cardiovascular, and Anti-inflammatory Activity.” J. Agric Food Chem. 56 (15): 6185-205.

[15] Patil, J. R., Chidambara-Murthy, K. N., Jayaprakasha, G. K., Chetti, M. B., and Patil, B. S. 2009. "Bioactive Compounds from Mexican Lime (Citrus aurantifolia) Juice Induce Apoptosis in Human Pancreatic Cells." J. Agric. Food Chem. 57 (22): 10933-42.

[16] Mannan, H., Ghazaleh, M., Seyed, M. M., Naficeh, S., Mohammad, R. O., and Behrooz, J. 2014. "Total Antioxidant Activity, and Hesperidin, Diosmin, Eriocitrin and Quercetin Contents of Various Lemon Juices.” Trop. J. Pharm. Res. 13 (6): 956.

[17] Serra, H., Mendes, T., and Bronze, M. R. 2008. "Prediction of Intestinal Absorption and Metabolism of Pharmacologically Active Flavones and Flavanones. Bioorg. Med. Chem. 16: 4009-18.

[18] Yeh, C. C., Kao, S. J., Lin, C. C., Wang, S. D., Liu, C. J., and Kao, S. T. 2007. "The Immunomodulation of Endotoxin-Induced Acute Lung Injury by Hesperidin in Vivo and in Vitro.” Life Science 80 (20): 1821-31.

[19] Ghorbani, A., Nazari, M., Jeddi-Tehrani, M., and Zand, H. 2012. "The Citrus Flavonoid Hesperidin Induces p53 and Inhibits NF- $\kappa$ B Activation in Order to Trigger Apoptosis in NALM-6 Cells: Involvement of PPAR $\gamma$ Dependent Mechanism.” Eur. J. Nutr. 51 (1): 39-46.

[20] Lee, K. H., Yeh, M. H., Kao, S. T., Hung, C. M., Liu, C. J., Huang, Y. Y., and Yeh, C. C. 2010. "The Inhibitory Effect of Hesperidin on Tumor Cell Invasiveness Occurs via Suppression of Activator Protein 1 and Nuclear FactorkappaB in Human Hepatocellular Carcinoma Cells." Toxicol. Lett. 194 (1-2): 42-9.

[21] Yeh, M. H., Kao, S. T., Hung, C. M.,Liu, C. J., Lee, K. H., and Yeh, C. C. 2009. "Hesperidin Inhibited
Acetaldehyde-Induced Matrix Metallopr-Oteinase-9 Gene Expression in Human Hepatocellular Carcinoma Cells." Toxicol. Lett. 184 (3): 204-10.

[22] Cui, B., Liu, S., Wang, Q., and Lin, X. 2012. "Effect of $\beta$-Carotene on Immunity Function and Tumor Growth in Hepatocellular Carcinoma Rats.” Molecules 17 (7): 8595-603.

[23] Kumar, B. H., Kumar, B. D., and Diwan, P. V. 2017. "Hesperidin, a Citrus Flavonoid, Protects against L-Methionine-Induced Hyperhomocysteinemia by Abrogation of Oxidative Stress, Endothelial Dysfunction and Neurotoxicity in Wistar Rats." Pharmaceutical Biology 55 (1): 146-55.

[24] Zini, G. 2014. "International Council for Standardization in Haematology. Stability of Complete Blood Count Parameters with Storage: Toward Defined Specifications for Different Diagnostic Applications (Editorial).” Int. Jnl. Lab. Hem. 36: 111-3.

[25] Thygesen, K., and Alpert, J. S. 2000. "Myocardial Infarction Redefined-A Consensus Document of the Joint European Society of Cardiology/American College of Cardiology Committee for the Redefinition of Myocardial Infarction.” JACC 36: 959-69.

[26] Sturgeon, C. 2002. "Practice Guideline for Tumer Marker Use in the Clinic." Clin. Chem. 48 (8): 1151-9.

[27] Armitage, P. 1974. Paired Student t-test In: Statistical Methods in Medical Research. Oxford and London: Blackwell Scientific Pub., pp. 116-20.

[28] Fuke, C., Nagai, T., Ninomiya, K., Fukasawa, M., Ihama, Y., and Miyazaki, T. 2014. "Detection of Imidacloprid in Biological fluids in a Case of Fatal Insecticide Intoxication.” Leg. Med. (Tokyo) 16: 40-3.

[29] Ansari, M. A., Keller, J. N., and Scheff, S. W. 2008. "Protective Effect of Pycnogenol in Human Neuroblastoma SH-SY5Y Cells Following Acrolein-Induced Cytotoxicity." Free Radic. Biol. Med. 45: 1510-9.

[30] Wambi, C., Sanzari, J., Wan, X. S., Nuth, M., and Davis, J. 2008. "Dietary Antioxidants Protect Hematopoietic Cells and Improve Animal Survival after Total-Body Irradiation." Radiation Research 169 (4): 384-96.

[31] Abd El-Rahman, N. A., Kamal El-Dein, E. M., Abd El-Hady, A. M., and Soliman, S. M. 2016. "Effect of Hesperidin on $\gamma$-Radiation and/or Paraquat Herbicide-Induced Biochemical, Hematological and Histopathological Changes in Rats." Pakistan J Zool. 48 (5): 1407-15.

[32] Czemin, J., and Waldherr, C. 2003. "Cigarette Smoking and Coronary Blood Flow." Prog. Cardiovasc. Dis. 45: 395-404. 